\title{
From expectation to experience: \\ humanizing childbirth in the Brazilian National Health System
}

Marília Mendes de Souza Teixeirense(a) Sara León Spesny Dos Santos ${ }^{(b)}$

Teixeirense MMS, Santos SLS. Da expectativa à experiência: humanização do parto no Sistema Único de Saúde. Interface (Botucatu). 2018; 22(65):399-410.

During the past 15 years Brazil has increased efforts to humanize maternal care within the Brazilian National Health System (SUS). Humanization efforts come along with de-medicalization of birth even if quality care and reduction of inequalities are still pressing matters in the country. For this qualitative study we interviewed ten women regarding their experiences of pregnancy and childbirth. The study took place in Brasília (DF) and women narrated their birth experiences at local hospitals or a birth center. Women were mostly satisfied with their attention during childbirth, specifically those giving birth at the birth center, in contrast to women giving birth at local hospitals. However, the humanization movement, essentializing women's bodies can also reproduce normative discourses that shape a sense of self-blame and disappointment if the 'ideal' birth is not achieved.

Keywords: Humanizing delivery. Birthing centers. Natural childbirth. Women's rights. Qualitative research.
Nos últimos 15 anos o Brasil redobrou os esforços para humanizar a atenção ao parto no Sistema Único de Saúde (SUS). Os esforços de humanização focaram na não medicalização do parto, nas desigualdades e na atenção de qualidade, que ainda são desafios reais no país. Neste estudo qualitativo entrevistamos dez mulheres sobre suas experiências de gravidez e parto. O estudo foi feito em Brasília e as mulheres narraram suas experiências de parto em hospitais e centro de parto normal, todos serviços do SUS. As mulheres demostraram satisfação com a atenção ao parto, mas com diferenças entre as mulheres atendidas no centro de parto normal e nos hospitais. Foi, também, identificado que o movimento de humanização pode essencializar os corpos das mulheres e reproduzir discursos normativos que influenciam sentimentos de culpa e decepção quando o parto 'ideal' não é alcançado.

Palavras-chave: Parto humanizado. Centros de assistência à gravidez e ao parto. Parto normal. Direitos da mulher. Pesquisa qualitativa. (a) Unidade Mista de Saúde de Taguatinga, Secretaria de Saúde do Distrito Federal. Área Especial, St. Central Qsb 1 C 12 BI N Taguatinga Sul. Brasília, DF, Brasil. 72010-120. mstmarilia@gmail.com

(b) Institut de recherche interdisciplinaire sur les enjeux sociaux (IRIS), École des Hautes Études en Sciences Sociales (EHESS). Paris, France. sara.leonspesny@ ehess.fr 


\section{Introduction}

\section{Birth in Brazil: From medicalization to humanization}

Eugenia was in her mid-twenties when she realized she was pregnant and actively sought a humanized birth experience. She looked for information from different channels- including a network of women who promoted 'humanized' birth attention in Brasília, the city she lived in. She used a mix of public and private care during her pregnancy, planning to give birth at a public facility but having a private physician in case she needed to have a C-section. Since home birth - her initial desire- was out of her budget, she went to a birth center with a doula, where she had a natural delivery. Eugenia narrated that she felt empowered and active during labor. She also recounted feeling pressured by some of the rather forcefully normative views of the humanized birth movement, within which women are expected to be able to give birth naturally, without interventions or medication, and doing otherwise can represent failure and disappointment. The transition towards motherhood is paved with pressures and fears. Indeed, women navigate through external and internal circumstances that shape their experiences of birth.

Eugenia's experience resonates with those of many women in contemporary Brazil. Even if not all options are equally available to women, and given that dramatic inequalities still persist in developing countries, contemporary childbirth options range from a medicalized birth, for instance a planned $\mathrm{C}$-section, to natural, drug and intervention-free vaginal birth.

Over the last decades, Brazil has consolidated an approach to maternal care largely based on what Robbie Davis-Floyd has called 'the technocratic model of birth'1. The dominance of this paradigm has resulted in Brazil having one of the world's highest $\mathrm{C}$-section rates, affecting both medical practices and women's desires and expectations. The country faces an 'epidemic' of C-sections, with staggering rates of $40 \%$ in public facilities and $84 \%$ in the private sector ${ }^{2}$. C-sections have been explained as a 'cultural preference' ${ }^{3}$ but this argument has been challenged as childbirth attention is "enmeshed in and generated by the day-to-day workings of specific socio-economic and political orders" 4 (p. 216). Nevertheless, C-sections have become a first choice not only for physicians but also for women themselves ${ }^{5}$. Excessive use of cesarean procedures in Brazil is a strong source of concern for those women who prefer a vaginal delivery. In this sense, Brazil has also strived to implement the international trend to 'humanize' attention "in maternal health systems of all kinds"6 (p. 395).

Efforts to humanize childbirth in Brazil started in the late 1970's and gained force through the $1990{ }^{\prime} \mathrm{s}^{7,8}$. The movement has seen more progress since 2000, with its introduction within the public health system (the Unified Health System, the SUS). Programs have been gradually introduced in the SUS, such as the Programa de Humanização no Pré-Natal e Nascimento (2000), the Programa Trabalhando com Parteiras Tradicionais (2000) and afterwards other programs such as Política Nacional de Atenção Integral à Saúde da Mulher (2004), the Pacto pela Redução da Mortalidade Materna e Neonatal (2004), and the Rede Cegonha-Stork Network- (2011). Throughout these national networks, birth is managed in different settings: hospitals, and clinics or birth centers (Centro de Parto Normal). The main goal of the birth centers is to deliver humanized assistance, centered in women's needs 9 . These centers have emerged as an option of maternal care under the public network (SUS) as part of the program Rede Cegonha. But the initiatives to reduce interventions (mainly C-sections) are now present in the private sector, for instance the initiative Projeto Parto Adequado ${ }^{10}$.

Civil society has also played an important role promoting and expanding ideas regarding humanization of birth, specifically raising awareness against obstetric violence and defending women's rights through associations and local networks. For instance, the Rede pela Humanização do Parto e Nascimento (Network for the Humanization of Birth or ReHuNA) established the Agreement on the Definition of Humanization and Humanized Care in the year 2000'11. Since then, networks and social movements have expanded in Brazil, initiating public debates and in some cases advocating and impacting local legislation ${ }^{5}$.

Humanization discourse derived from a critique of medicalization, and represents a form of resistance ${ }^{12}$. But even if both perspectives have become almost opposite, this polarization has not been 
absolute. In fact, the divide between 'natural' and 'biomedical' or technocratic ${ }^{13}$ perspectives have actually given way to less opposing, and more nuanced definitions ${ }^{14}$.

The increasing popularization of humanization and its evolving integration within the biomedical system has also raised new questionings regarding normative understandings of the body and reproduction. Indeed, both perspectives might actually reinforce a common understanding of the ability to control reproduction, whether it is by means of biomedical knowledge and technology or midwifery's presumption of women's natural power to reproduce ${ }^{15}$. And indeed, the efforts to integrate humanization practices within the public system have changed the landscape of maternal care.

In this article we focus on the experiences of women who sought humanized care and gave birth in a public facility in Brasília, Brazil. It is precisely within the intersection of the public health system and the humanization movement that we place our attention, viewing this intersection as a conceptual space within which women's expectations and ideologies of birth are confronted with the care they receive during pregnancy and birth, and their conceptions of the body and experience come into focus.

\section{Methodology}

\section{Qualitative research}

This research took place in the Federal District of Brazil, Brasilia. We mapped local networks and prenatal associations through the Internet. We contacted the organizers of these networks and they referred us to women who gave birth in public institutions and were willing to participate. Data was thus collected using key informants and networks through snowballing. A group of ten women was selected based on the following criteria: Had their birth at a public facility, were 18 years old or older, and gave birth between July 2012 and July 2013. While most of our interviewees were actively engaged with the humanized birth movement, not all of them were part of a network or an association or were inclined towards humanized birth, giving variety to our sample. Semi structured interviews guided questions that included experiences with prenatal, birth and postnatal care, quality of assistance, information and procedures received, contact with health professionals and overall experience of childbirth. All interviews were recorded and transcribed in Portuguese shortly afterwards by the first author. Data were analyzed in Portuguese and the final results and selected quotations were translated to English and further interpreted by the second author.

Data analysis was conducted in five stages: 1) familiarization 2) identification 3) indexing 4) mapping 5) interpretation ${ }^{16,17}$.

We established the following categories for analysis: Access to information about rights; quality of the birth experience; quality of assistance and care.

Interviewees signed a consent form before the interview. The Ethical Committee of the Faculty of Health (University of Brasilia-UnB) approved this research (Protocol no: 50/13 Date: 09 April 2013). Names in this article are pseudonyms. Interviews took place in a location convenient for the participants.

Taking into account that entanglement between research and biographical trajectories is "crucial in dialogues about maternity care"18 (p. 694) for us, further contact with networks also came from personal experience. At the time of this research, both authors were pregnant. As participants in some of these networks, we encountered many women, along with nurses and doulas who shared their thoughts and experiences. Both authors were supporters of natural birth, and expected to have a 'humanized' experience. This stance necessarily affected our critical review of the data three years later. We placed our research in engagement with women's wellbeing, in some cases actively notifying them about rights and legislation for instance, the right to have a companion during labor and birth Lei $11.108-^{-19}$. 


\section{Results and discussion}

\section{Women's profiles}

Most of the women we interviewed were married or lived in a stable union by the time the interviews took place and spent their pregnancies accompanied by a partner. Two of them were single. Their ages varied from 19 to 37 years old. Their levels of formal education also varied largely: Five had completed undergraduate studies, two were undergraduate students, one had finished high school, and two had not completed basic education. Six women were multiparous -with previous vaginal and $\mathrm{C}$-section birth experiences- while four were nulliparous. One had a previous delivery, a stillborn. Half of them had their birth in a local birth center and the other half in public hospitals, located in peripheral cities of Brasília's Plano Piloto.

Some women mentioned using public and private services interchangeably, but all of them had a vaginal birth at a public facility. Private and public sectors are often used in complementary ways in Brazil, as private healthcare has extended a great deal over the past years ${ }^{20}$. Three of them hired the private assistance of a doula, specifically those who delivered at the birth center.

Some women migrated from private to public care because the private obstetricians they initially saw openly declared being pro-C-sections.

\section{Maternal care: Rights, information and assistance}

According to most women, there is a lack of information given by the public prenatal care system. Those women engaged with natural birth sought to fill these gaps through other channels of information, such as books, the Internet, and social networks. On another hand, most women felt their rights during childbirth were respected, and the doubts they had were clarified, as most of them were actively asking questions. While women who attended the birth center were granted the right to an accompanied birth, those who attended local hospitals were often denied this legal entitlement.

Most participants claim they received insufficient information regarding their future births:

I looked for other information, the primary care facility (o posto) was really only for the physical exam, I didn't receive any information about birth. (Elena)

They only informed me about normal birth and C-section. (Rafaela)

They only gave us a talk about how to take care of a baby. (Tatiane)

Women who received private care expressed that physicians talked about C-sections:

He told me it was bad [vaginal birth], that it was really painful, he really tried to convince me that a C-section was better. (Eliane)

She [physician] told me that I wasn't going to be able to do it [vaginal birth] that the baby was too big, that I wasn't going to be able, that I was anemic. (Edith)

Women have the right to make a prenatal visit to the facility where they will give birth. But two women weren't offered this possibility and two other women were offered but could not attend.

Interviewees explained how they looked for different sources of information, including being active during their prenatal visits in the primary center:

I looked for information in blogs. I found out about a book from Michel Odent [...] I attended the prenatal group of a [university] hospital, since the very beginning of my pregnancy.

(Eugenia) 
I looked for information with a colleague, she was also pregnant, and she read a lot of things on the Internet, and I would look at those things. (Susana)

So, the Internet, books, my doula taught me, she was very important for this, she oriented me, informed me. (Edith)

For six of the ten women their right to have a partner during labor was respected; five of them gave birth at the birth center. Three women mentioned being denied this right by the hospital staff. Roberta and Tatiane were not accompanied during labor and at the time they did not know about this right, whereas Rafaela mentioned that even though she knew about the law, the institution -a local hospital- denied the entrance of a companion: "They told me that I could not have one [companion during labor] (...) Every other woman there didn't have a companion either" (Rafaela).

Studies have shown that quality of care in Brazil is insufficient and women's rights established by law are not systematically applied throughout the country ${ }^{21-24}$. However, the staff plays an important role in the evaluation of quality care ${ }^{25}$. Having support during labor has been scientifically shown to enhance the quality of women's birth experiences, specifically a partner, in case there is one, and also a doula, if permitted ${ }^{26}$.

Despite some issues regarding respect for women's rights during childbirth, half of our interviewees expressed having some sort of doubt during labor that ended up being appropriately addressed by the staff. Information alone does not prevent unnecessary invasive procedures during childbirth, but it does enhance women's decision making abilities and has other psychosocial benefits ${ }^{27}$.

While prenatal attention and information help women to prepare for birth, during the labor process, intense emotions and sensations intertwine. As we will explore in the following section, the unpredictability of birth makes labor a delicate time, both physiologically and emotionally, and the experience of birth is strongly marked by how these decisions and emotions interplay.

\section{Birth: Decisions \& emotions under control?}

Women mostly described feeling in control while making decisions taken during labor and birth. The dualistic view of feeling in control vs out-of control was present in women's narratives, and while pregnancy and childbirth are largely uncontrollable processes, there is a set of cultural mandates "to assume greater responsibility for bodily functions" 28 (p. 995). So generally women's ability to control is somewhat expected, while losing control is condemned.

Most women did have some sort of intervention during the labor process. Artificial oxytocin was administered to four of the interviewees, amniotomy and episiotomy were mentioned by three and the Kristeller maneuver (uterine fundal pressure) by one of the interviewees. But while interventions during labor were common, women accepted and often came to believe that these procedures were necessary:

She [the nurse] asked if I wanted [oxytocin], because the labor was not developing, I decided to take it and accelerate labor, because I was already too tired. (Susana)

I could have waited a bit longer, but I was really tired, and I really wanted it to end quickly. (Elena)

All of my doubts were clarified, I was very well oriented. (Roberta)

The amniotic sac did not break, he [the baby] was going to come out with it, but I really wasn't able to do it, I was under too much pain, it really was too hard, that's why I think [the amniotomy] was necessary. (Edith) 
Women who gave birth at the birth center described having interventions with consent and after receiving appropriate information. When making these decisions, interviewees described having in mind their goal to accelerate labor and diminish discomfort. Thus, decisions are described as somewhat under control. However, women who received attention at local hospitals did not feel they made decisions and felt less active during the process. These women were not informed as often about the interventions and did not have active participation during labor: "They simply did not ask anything". (Eliane)

When asked about participating in the process, Carmen and Tatiane -who had their births in different local hospitals- answered with a definitive 'no'.

The lack of participation regarding women who gave birth in local hospitals seems to contradict the overall satisfaction interviewees expressed regarding the maternal care they received. This discrepancy might indicate that women's main criterion to evaluate their experience is related to the most desired outcome: A healthy baby. To have a healthy baby might often make 'everything worth it' or might 'make one forget' the endurances of labor, including quality of care, unnecessary interventions or lack of participation during the process.

While decisions were portrayed as controlled, emotions were mostly portrayed as out of-control. Both fear and pain were central to these women's birth narratives. Fear -an emotion- was mostly associated with doubting one's ability to give birth and reflected the attitudes of others who also seemed to doubt them, while pain -a sensation- was the most significant physical experience of birth. Women expressed having difficulties to direct emotions:

I started to get scared, what if I can't make it? [...] I won't be able to take this baby out of here! (Eugenia)

I feared of something going wrong, of having some sort of problem, fetal distress, a C-section, fear of an interventionist nurse. (Aisa)

I felt anxiety, to see his face, for it [the birth] to be over, for that pain to go away. (Elena)

Fear was one of the most salient emotions expressed in women's narratives. Their fear was not only related to the physiological aspects of birth, such as ability to push, or unexpected health problem with the fetus, but also with the context, such as health professional's attitudes and tendencies to intervene. As we will explore in the next section, pain is at the very center of the experience, and is constantly symbolized as negative. After the delivery, feelings varied from relief and happiness, but were less emphasized in women's narratives.

\section{Humanization: Lines between expectation and experience}

Nevertheless, interviewed women described their birth experiences mainly as positive- especially those delivering at the birth center. Some negative experiences (regarding lack or negative attention received from hospital staff) but also individual factors (difficulty and level of pain or a previous difficult experience) can deeply mark the birth experience and shape women's narratives regarding their overall evaluation of birth. In this sense, quality care and satisfaction of women were highly influenced by location; women giving birth in the birth center expressed feeling protagonistic during the process. Most of these women felt that the staff respected them, but highlighted their own active roles during the process. Elena's testimony best describes this sense of protagonism: "I felt extremely respected during the process [...] I had autonomy, empowerment, but I think it was because I aimed for that" (Elena).

In contrast, giving birth at a local hospital, Carmen and Eliane expressed feeling insulted and threatened and did not feel respected: 
He [the physician] called me an ignorant, he said that having three children I should be calmer $[\ldots]$ he refused to assist me. (Carmen)

I was very uncomfortable, during the whole time I felt threatened, if I didn't do what they asked, I would get a C-section. The first physician asked me to stop screaming. (Eliane)

As some studies have shown ${ }^{29}$ when women feel disrespected or do not trust the staff they make an effort to suffer less humiliation, adapting to the expectations of health professionals. A silent birth, for instance, would exemplify one of these efforts. Accordingly, women's experiences regarding birth varied significantly regarding place of birth, as we have also emphasized above. Those giving birth at the birth center described positive experiences:

God it was wonderful! My experience was wonderful, it was good, very good! (Eugenia)

It was painful, it was a lot of work, but I really enjoyed it [...] it was great. (Edith)

Even though one of the humanization premises is to deconstruct the central role of pain during labor and birth ${ }^{11}$ the centrality of pain was found consistently in every narrative among the ten women. Indeed, throughout its development, the natural childbirth movement has conceptualized the notion of pain as positive and empowering, giving the women a chance to go deep inside herself to find the strength to labor and birth and bask in the glow of that feeling that 'I did it!' ${ }^{30}$. This normative humanistic discourse can make women feel that they must 'measure up' to a predetermined ideal of 'natural' childbirth ${ }^{31}$. Yet pain remained dominant in their narratives:

I felt too much pain. I was trembling from head to toes from the pain, this was very surprising from me. (Rafaela)

I really felt dominated by the pain, the only thing I felt was pain. (Elena)

I didn't expect to be under so much pain, I didn't know it was going to be that painful.

(Eugenia)

Often women's ideal birth contrasted significantly with their actual birth experience. And even if most women did receive humanized care, we saw that many of them did have some sort of interventions and their narratives reveal that derailment from the ideal plan can cause regret: "I found it was good, I would correct the mistake of allowing medication and episiotomy" (Eliane).

The experiences of women who gave birth in local hospitals reveal that in these settings the biomedical model is still predominant and institutional dynamics still disregard federal guidelines and legislation. Opposing this model, women who gave birth in the birth center were more satisfied with their experiences.

But confusingly, modern discourses of motherhood seek to encourage women not only to participate in, but also to be the protagonist of their birth experiences, while, at the same time, seeming to hold them responsible for the 'failure' of a less than ideal birth experience. Self-blame often shapes women's perceptions when the real birth experience differs from their 'ideal' expectation. The divergence between expectation and experience can cause frustration. These feelings that result inadvertently from humanized discourses are the subject of the following section.

\section{Disciplining (women's bodies) and humanizing (health professionals)}

Birth is often the terrain of different disciplinary discourses, in which biomedicine and midwifery, as well as feminism, display and confront their contradictive and apparent irreconcilable views ${ }^{32}$. 
As we have seen, the medicalized or technocratic view is contrasted with the humanized view: One is labeled as authoritarian, vertical and interventionist; the other as lateral, gentle, respectful and participatory. And while the humanized model encompasses physiological as well as subjective advantages for women, it is not immune to attempts at enforcement of normative views of women's bodies as strong and fully capable of giving birth. Normative views that circulate within humanistic networks can indeed enhance confidence and autonomy, but at the same time can encompass strong ideas about women's bodies based on their 'natural' capability to give birth. For instance, in some prenatal groups, women were encouraged to become 'empowered':

She [the coordinator of the network] talked a lot about pain, that pain was psychological and that it's part of the process... that we are capable, every women is capable and has to become empowered with our bodies. (Eugenia)

I understand birth as a physiological process that our body has done for millions of years, right? And my son and I would be capable of going through it. (Elena)

Humanized birth for me it's ideal! Every mother has to experience it! (Susana)

A feeling of winning, of overcoming. (Edith)

Yet feelings of guilt can accompany failure to achieve the idealistic view our interviews expressed above. Looking through the narratives of empowerment and contrasting them with the desired birth, we found that women often reveal feelings of self-blame and regret. So, the construction of decisive and participatory experience can also become a burden for women who seek a humanized experience. Additionally, the monopolized idea of a 'happy ending' shadows the complicated, nuanced and sometimes sad outcomes of pregnancy and birth ${ }^{15}$. Roberta embodies the potential traumatic outcome of birth, her baby was stillborn and her narrative is far from the 'ideal' birth.

In this sense, while humanized ideas and concepts might encourage active and participatory women, the natural childbirth movement can also essentialize women to being only their bodies. Here, a strict adherence to a set of 'humanized' discourses can be experienced as "disciplining and controlling rather than empowering" 33 (p. 749).

In this dualist view we must also acknowledge social and economic backgrounds that strongly influence women's horizons of possibilities and experiences ${ }^{34,35}$. As seen in some cases, women express some limitations that influenced their birth choices:

I didn't have the money to have a home birth. (Eugenia)

I always knew I didn't want a hospital delivery [...] so I thought that the birth center was a good option. (Elena)

I wanted at home, but it is too expensive. (Aisa)

Home birth as a birth choice -the epitome of a post-modern humanized birth ${ }^{36}$ - is mainly a luxury confined to the middle and upper classes. The birth center where care is government-funded emerges as a safe, accessible option, for those who qualify. Here, health professionals are aware of woman's participation and the institutional dynamic allows and encourages humanized birth.

In general, women with lower levels of education had economic difficulties in achieving most of the 'ideal' conditions of their rights, such as making a visit to the public facility or having a companion during labor and birth.

Inequalities in maternal health are associated with age, formal education level, labor and race as well as other socio-economic factors, which greatly impact quality of care $^{37}$. Also, childbirth attendance in public facilities varies greatly from one facility to another ${ }^{38}$. But even though translating humanized 
discourse into practice has been difficult 39,40 and obstetric violence is still a serious issue ${ }^{41}$, health providers in some facilities are increasingly responsive to humanized models of care ${ }^{42}$.

The variation in institutional dynamics and guidelines greatly influence the quality of support provided by staff, and the degree of respect for legislation exhibited by that hospital; some hospital staff, influenced by the humanistic movement work to empower their patients ${ }^{24}$. Indeed, childbirth patterns are a matter of organizational culture ${ }^{43}$ and women's experiences are enmeshed within larger dynamics and shaped by structural factors.

\section{Conclusion}

Almost all interviewed women were actively engaged in seeking information regarding their rights, obstetric violence and quality of care. While this finding may be a bias of our results, it can also point towards the increasing demands made by the women in Brazil who seek a natural 'humanized' birth. Following international recommendations -mainly those of the World Health Organization- public health care has increasingly adopted humanization initiatives set to de-medicalize routine birth experiences. For women with low risk pregnancies public birth centers have become a viable option. In contrast, women with pregnancies deemed to be high risk will not have this opportunity.

Even though the humanization of childbirth is acknowledged internationally and has been progressively implemented throughout Brazil, staggering inequalities still exist regarding access to humanized birth and quality care. So, even with more than a decade of initiatives to de-medicalize and humanize maternity care there are still many challenges to accomplishing that goal, which primarily include resistance from highly technocratized obstetricians $\mathrm{s}^{7,44}$.

By analyzing narratives of women and their experiences we simultaneously address the expectations of women across the spectrum but also the inequalities that persist in maternal care in Brazil. For instance, the number of birth centers in Brazil is quite small in comparison to the number of hospitals. This lack of access to humanized birth greatly limits the possibilities of low-income women to have access to humanized care.

In our study, five out of ten women gave birth in one of these centers and they narrated better attention, higher satisfaction and better quality of care when compared to women who gave birth in local hospitals. These women actively sought to give birth in a specific facility hoping for quality care, which they did indeed receive. Most women sought more information beyond their pre-natal care in public facilities, specifically regarding their rights, which was a cause for concern before birth. These channels of information, such as books, the Internet, other women's experiences, doulas, associations and networks often promote humanization practices. During birth, these women felt mostly participatory. Just as access to prenatal care during pregnancy strongly diminishes maternal and perinatal mortality, access to quality information and rights is seen to generate a positive evaluation of the experience.

However, discourses surrounding the humanization movement should be given further consideration, taking into account some normative views of women's bodies and birth, specifically as they can imply a sense of failure and self-blame if women do not attain the expected experience. While women described feeling active in decision-making, their emotions were not controlled and the centrality of pain can be related to feelings of disappointment. Women expressed pressures to perform, attain and fulfill certain normative standards, capacities and functions labeled as 'natural' and 'ideal'.

While it is difficult to establish whether there is a nationwide increasing demand for de-medicalized and humanized frameworks of attention by Brazilian women at large, the imperative to implement guidelines and practices to achieve better quality of care has recently become an important goal for many public healthcare workers in Brazil. How the experiences and subjectivities of women are shaped in this changing landscape is a remaining area of study for health professionals, social scientists and advocates of women-centered birth practices. 


\section{Contributors}

Marília carried out recorded interviews and transcribed them. Data were analyzed in Portuguese by both authors and the final results and selected quotations were translated to English and further interpreted by Sara. Sara made the outline of the article and updated analysis with bibliographic references. Both authors were active in the discussion of final results and participated in the revision and approval of the final version of this manuscript.

\section{References}

1. Davis-Floyd R. The technocratic, humanistic, and holistic paradigms of childbirth. Int J Gynaecol Obstet. 2001; 75 Suppl 1: 5-23.

2. Ministério da Saúde (BR). Partos normais e cesáreas [Internet]. 2015 [cited Oct 26 2016]. Available from: http://promocaodasaude.saude.gov.br/promocaodasaude/ assuntos/incentivo-ao-parto-normal/noticias/partos-normais-e-cesareas.

3. Barbosa GP, Giffin K, Angulo-Tuesta A, Gama AS, Chor D, D'Orsi E, et al. Cesarean sections: who wants them and under what circumstances? Cad Saude Publica. 2003; 19(6):1611-20.

4. McCallum C. Explaining caesarean section in Salvador da Bahia, Brazil. Sociol Health Illn. 2005; 27(2):215-42.

5. Leão MR C, Riesco MLG, Schneck CA, Angelo M. Reflections on the excessive rates of cesareans in Brazil and the empowerment of women. Cienc Saude Colet. 2013; 18(8):2395-400.

6. MacDonald ME. The cultural evolution of natural birth. Lancet. 2011; 378(9789):394-5.

7. Rattner D. Humanizing childbirth care: pondering on public policies. Interface (Botucatu). 2009; 13 Suppl 1:759-68.

8. Diniz CSG. Humanization of childbirth care in Brazil: the numerous meanings of a movement. Cienc Saude Colet. 2005; 10(3):627-37.

9. Machado NXS, Praça NS. Delivery center and obstetric assistance focused on the parturient's needs. Rev Esc Enferm USP. 2006; 40(2):274-9.

10. Agência Nacional de Saúde Suplementar. Cartilha nova organização do cuidado ao parto e nascimento para melhores resultados de saúde : Projeto Parto Adequado - fase 1. Brasília: Agência Nacional de Saúde Suplementar, Sociedade Beneficente Israelita Brasileira Hospital Albert Einstein, Institute for Healthcare Improvement; 2016.

11. Page L. The humanization of birth. Int J Gynecol Obstet. 2001; 75 Suppl 1:55-8.

12. Parry D. "We wanted a birth experience, not a medical experience": exploring Canadian women's use of midwifery. Health Care Women Int. 2008; 29(8-9):784-806.

13. Davis-Floyd R. Birth as an American Rite Of Passage. 2nd ed. California: University of California Press; 1992.

14. Macdonald M. Gender expectations: natural bodies and natural births in the New Midwifery in Canada. Med Anthropol Q. 2006; 20(2):235-56.

15. Layne LL. Unhappy endings: a feminist reappraisal of the women's health movement from the vantage of pregnancy loss. Soc Sci Med. 2003; 56(9):1881-91.

16. Mays N, Pope C. Assessing quality in qualitative research. BMJ. 2000; 320(7226):50-2.

17. Pope C, Mays N. Qualitative research in health care. New York: John Wiley \& Sons; 2006. 169 p. 
18. Oakley A. The sociology of childbirth: an autobiographical journey through four decades of research. Sociol Health Illn. 2016; 38(5):689-705.

19. Ministério da Saúde (BR). Lei no 11.108, de 7 de abril de 2005. Altera a Lei no 8.080, de 19 de setembro de 1990, para garantir às parturientes o direito à presença de acompanhante durante o trabalho de parto, parto e pós-parto imediato, no âmbito do Sistema Único de Saúde - SUS. Diário Oficial da União

20. Machado JP, Martins M, Leite IC. O mix público-privado e os arranjos de financiamento hospitalar no Brasil. Saude Debate. 2015; 39(spe):39-50.

21. Figueiredo PPD, Rossoni E. O acesso à assistência pré-natal na atenção básica à saúde sob a ótica das gestantes. Rev Gaucha Enferm. 2008; 29(2):238.

22. Ceron MI, Barbieri Â, Machado Fonseca L, Fedosse E. Prenatal care in the perception of postpartum women from different health services. Rev CEFAC. 2012; 15(3):653-62.

23. Polgliane RBS, Leal MC, Amorim MHC, Zandonade E, dos Santos Neto ET. Adaptation of the process of prenatal care in accordance with criteria established by the Humanization of Prenatal and Birth Program and the World Health Organization. Cienc Saude Colet. 2014; 19(7):1999-2010.

24. Brüggemann OM, Ebsen ES, Ebele RR, Batista BD, Brüggemann $O M$, Ebsen ES, et al. Possibilities of inclusion of the partner in deliveries in public institutions. Cienc Saude Colet. 2016; 21(8):2555-64.

25. Carraro TE, Knobel R, Frello AT, Gregório VRP, Grüdtner DI, Radünz V, et al. O papel da equipe de saúde no cuidado e conforto no trabalho de parto e parto: opinião de puérperas. Texto Contexto Enferm. 2008; 17(3):502-9.

26. Santos JO, Tambellini CA, Oliveira SMJV. Presença do acompanhante durante o processo de parturição: uma reflexão. Reme, Rev Min Enferm. 2011; 15(3):453-8.

27. Dias MAB, Domingues RMSM, Pereira APE, Fonseca SC, Gama SGN, Filha T, et al. The decision of women for cesarean birth: a case study in two units of the supplementary health care system of the State of Rio de Janeiro. Cienc Saude Colet. 2008; 13(5):1521-34.

28. Carter SK. Beyond control: body and self in women's childbearing narratives. Sociol Health IIIn. 2010; 32(7):993-1009.

29. Hotimsky SN, Rattner D, Venancio SI, Bógus CM, Miranda MM. Childbirth as I see it.... or the way I wish it was?: expectations of pregnant women towards childbirth and obstetric care in the public health care system. Cad Saude Publica. 2002; 18(5):1303-11.

30. Arney WR, Neill J. The location of pain in childbirth: natural childbirth and the transformation of obstetrics. Sociol Health Illn. 1982; 4(1):1-24.

31. Carson A, Chabot C, Greyson D, Shannon K, Duff $P$, Shoveller J. A narrative analysis of the birth stories of early-age mothers. Sociol Health IIIn. 2017; 39(6):816-31.

32. Lee ASM, Kirkman M. Disciplinary Discourses: Rates of Cesarean Section Explained by Medicine, Midwifery, and Feminism. Health Care Women Int. 2008; 29(5):448-67.

33. Malacrida C, Boulton T. Women's perceptions of childbirth "choices": competing discourses of motherhood, sexuality, and selflessness. Gend Soc. 2012; 26(5):748-72.

34. Martin E. The woman in the body: a cultural analysis of reproduction. Boston: Beacon Press; 2001.

35. Liamputtong P. Birth and social class: Northern Thai women's lived experiences of caesarean and vaginal birth. Sociol Health IIIn. 2005; 27(2):243-70.

36. Davis-Floyd R. Daughter of time: the postmodern midwife. MIDIRS Midwifery Dig. 2005; 15(1):32-9. 
37. Nagahama EEI, Santiago SM. Humanization and equity in labor care in a Southern Brazilian city. Acta Paul Enferm. 2008; 21(4):609-15.

38. Nagahama EEI, Santiago SM. Humane childbirth and type of childbirth: an evaluation of care provided by the brazilian national health system in a city in the south of Brazil. Rev Bras Saude Materno Infant. 2011; 11(4):415-25.

39. Souza TG, Gaíva MAM, Modes PSSA. The humanization of birth: perception of health professionals working in the delivery. Rev Gaucha Enferm. 2011; 32(3):479-86.

40. Merighi MAB, Gualda DMR. Mothers'health in Brazil and recovering the training of midwives for care in the birth process. Rev Latino-Am Enfermagem. 2009; 17(2):265-70.

41. Diniz SG, Salgado HDO, Aguiar Andrezzo HF, Cardin de Carvalho PG, Albuquerque Carvalho PC, Azevedo Aguiar C, et al. Abuse and disrespect in childbirth care as a public health issue in Brazil: origins, definitions, impacts on maternal health, and proposals for its prevention. J Hum Growth Dev. 2015; 25(3):377.

42. Malheiros PA, Alves VH, Rangel TSA, Vargens OMC. Labor and birth: knowledge and humanized practices. Texto Contexto Enferm. 2012; 21(2):329-37.

43. Behruzi R, Hatem M, Goulet L, Fraser W, Misago C. Understanding childbirth practices as an organizational cultural phenomenon: a conceptual framework. BMC Pregnancy Childbirth. 2013; 13:205.

44. Rattner D. Humanização na atenção a nascimentos e partos: breve referencial teórico. Interface (Botucatu). 2009; 13 Supl 1:595-602.

Teixeirense MMS, Santos SLS. De la expectativa a la experiencia: humanización del parto en el Sistema Brasileño de Salud. Interface (Botucatu). 2018; 22(65):399-410.

Durante los últimos 15 años Brasil redobló los esfuerzos para humanizar la atención al parto en el Sistema Brasileño de Salud(SUS). Los esfuerzos de humanización se enfocaron en la no medicalización del parto, en las desigualdades y en la atención de calidad, que todavía constituyen desafíos reales en el país. En este estudio cualitativo entrevistamos a diez mujeres sobre sus experiencias de embarazo y parto. El estudio se realizó en Brasilia (DF) y las mujeres narraron sus experiencias de parto en hospitales y en centros de parto normal, todos ellos servicios del SUS. Las mujeres demostraron satisfacción con la atención al parto, pero con diferencias entre las mujeres atendidas en el centro de parto normal y en los hospitales. También se identificó que el movimiento de humanización puede hacer esenciales los cuerpos de las mujeres y reproducir discursos normativos que influyen sobre sentimientos de culpa y decepción cuando no se consigue el parto 'ideal'.

Palabras clave: Parto humanizado. Centros de asistencia al embarazo y al parto. Parto normal. Derechos de la mujer. Encuesta cualitativa.

Submitted in 21/11/16. Approved in 03/10/17. 